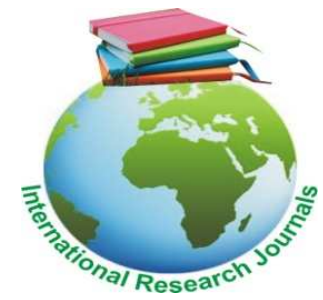

International Research Journal of Agricultural Science and Soil Science (ISSN: 2251-0044) Vol. 7(4) pp. 058-067, December, 2017

Available online http://www.interesjournals.org/IRJAS

DOI: http:/dx.doi.org/10.14303/irjas.2017.059

Copyright (C) 2017 International Research Journals

Full Length Research Paper

\title{
Soil properties and yield of pepper (Capsicum chinenseJacq.) as influenced by Almond leaf-based compost and tillage in Ibadan, Nigeria
}

\author{
${ }^{*}$ Ogunsesin A. and Aiyelari E. A. \\ Department of Agronomy, University of Ibadan, Nigeria \\ *Corresponding Author's E-mail:ogunsesinayorinde@yahoo.com
}

\begin{abstract}
Soil properties and yield of pepper are affected by soil fertility and cultural practices such as tillage. Although, composts improve soil structure and enhance soil fertility and crop yield, limited information is available on the combined effect of tillage and compost on the yield of pepper. Therefore, a study was conducted in 2010 and 2011 to evaluate the effect of almond leaf-based composts on soil properties and yield of $C$. chinense under the two commonly practiced tillage systems in Ibadan. The influence of thirteen experimental treatments comprising of almond leaf-based composts [Almond leaves + Poultry manure (AP) at 9.7, 12.1, and $14.5 \mathrm{t} / \mathrm{ha}$; Almond leaves + Cattle manure (AC) at 14.3, 17.9, and $21.5 \mathrm{t} / \mathrm{ha}$; and Almond leaves + Swine manure (AS) at 13.0, 16.3, and 19.6 t/ha]; NPK 15-15-15 at 0.2, 0.25, and $0.3 \mathrm{t} / \mathrm{ha}$; and a control (without fertilizer) on the growth and yield of $C$. Chinense were investigated in a Screen house. Each treatment was mixed with $5 \mathbf{~ k g}$ soil and arranged in a completely randomized design with four replications. The performances of the best rates in each treatment: AP (14.5 t/ha), AC (14.3 t/ha), AS (13.0 t/ha), NPK (0.25 t/ha) and control from Screen house studies, under two tillage methods: Manual Clearing (MC) and Manual Ridging (MR) were investigated in the field. The ten treatment combinations (MC; AP/MC; AC/MC; AS/MC; NPK/MC; MR; AP/MR; AC/MR; AS/MR and NPK/MR) were laid as randomised complete block design with four replications. Data were collected on plant height (PH), number of leaves (NL), and number of branches (NB), stem girth (SG), root length (RL) and fruit yield (FY) of pepper. Soil samples were collected and analysed for changes in nutrient content, soil porosity (SP), bulk density (BD), soil temperature (ST) and pH. Data were analysed using descriptive statistics and ANOVA at $\alpha_{0.05}$. In the Screen house, significant $(p<0.05)$ differences were observed among the treatments for PH, NL, NB, SG and FY of pepper. The FY ranged from $44.5 \pm 1.7$ (control) to $68.4 \pm 3.1 \mathrm{~g} / \mathrm{pot}$ (AC, $14.3 \mathrm{t} / \mathrm{ha}$ ). The highest FY of $68.4 \pm 3.1 \mathrm{~g} /$ pot of pepper recorded by $A C(14.3 \mathrm{t} / \mathrm{ha})$ was higher than those from NPK $(0.25 \mathrm{t} / \mathrm{ha})$ by $13.6 \%$. In the field; PH, NL, NB, RL and SG of pepper were significantly $(\mathrm{p}<0.05)$ higher under MR than MC, respectively. The SP $(54.4 \pm 1.6$ and $46.4 \pm 1.8 \%)$, carbon $(18.5 \pm 1.7$ and $14.4 \pm 1.4 \mathrm{~g} / \mathrm{kg})$, nitrogen $(4.3 \pm 0.4$ and $3.3 \pm 0.4 \mathrm{~g} / \mathrm{kg}), \mathrm{K}(0.3 \pm 0.1$ and $0.2 \pm 0.1 \mathrm{cmol} / \mathrm{kg})$, calcium $(10.5 \pm 1.0$ and $8.3 \pm 0.9 \mathrm{cmol} / \mathrm{kg})$, CEC (15.9 $\pm 1.3 \mathrm{and}$ $13.4 \pm 1.2 \mathrm{cmol} / \mathrm{kg})$ and $F Y(6.6 \pm 0.6$ and $3.6 \pm 0.3 \mathrm{t} / \mathrm{ha})$ were significantly $(p<0.05)$ higher under MR than MC, respectively. The BD and ST under MR were not significantly $(p<0.05)$ different from MC. The FY under almond leafbased composts increased in the order: AS $(5.0 \pm 0.7 \mathrm{t} / \mathrm{ha})<\mathrm{AP}(5.3 \pm 0.7 \mathrm{t} / \mathrm{ha})<\mathrm{NPK}(5.7 \pm 0.8 \mathrm{t} / \mathrm{ha})<\mathrm{AC}(6.9 \pm 1.1 \mathrm{t} / \mathrm{ha})$. Soil $\mathrm{pH}$ under compost-tillage $(6.8 \pm 0.1)$ was higher than that of NPK-tillage $(5.4 \pm 0.1)$ combinations. The SOC $(25.5 \pm 2.7 \mathrm{~g} / \mathrm{kg}), \mathrm{N}(6.4 \pm 0.6 \mathrm{~g} / \mathrm{kg}), \mathrm{K}(0.5 \pm 0.2 \mathrm{cmol} / \mathrm{kg}), \mathrm{SP}(59.5 \pm 0.9 \%)$ and $\mathrm{FY}(10.0 \pm 0.5 \mathrm{t} / \mathrm{ha})$ under the combination of $14.3 \mathrm{t} / \mathrm{ha} \mathrm{AC} / \mathrm{MR}$ was significantly $(\mathrm{p}<0.05)$ higher than other treatments. Soil properties and yield of pepper were greatly improved under almond leaf-based compost and manual ridging. Thus, the combination of almond leavescattle manure compost at $\mathbf{1 4 . 3} \mathrm{t} / \mathrm{ha}$ and manual ridging is recommended for enhancing soil properties for pepper production in Ibadan.
\end{abstract}

Keywords: Compost manure, Almond leaves, Pepper fruit yield, Manual ridging, Manual clearing

\section{INTRODUCTION}

Peppers are vegetables rich in bioactive nutrients such as ascorbic acid, carotenoids and phenolic compounds.
They are used extensively in food flavouring in the daily diet of over 140 million Nigerians, irrespective of their 
social and economic status (Asawalam et al., 2007). Hence, there is need to increase the production of pepper to meet the market demand of the ever-increasing population of Nigeria. The world production of Capsicum pepper is about 21.3 million t/ha/annum, out of which 1 million t/ha is attributed to tropical Africa. This is abysmally low compared to 1.5 and 10.0 million t/ha produced annually in Turkey and China, respectively. Nigeria produces about 715,000 t/ha annually; this only contributes $3 \%$ to the world production (FAO, 2001). One of the major factors responsible for low production of Capsicum pepper in tropical Africa is low soil fertility.

Hanson (1992) reported that out of 3 billion hectares of arable land in tropical Africa, only $14.7 \%$ is free of physical and chemical constraints. This shows that about $85.3 \%$ of the soils are inherently low in soil fertility. Consequently, the yield of crops like pepper is significantly affected by the level of soil fertility. As a result, chemical fertilizers are usually used to augment soil fertility for crop production (pepper) in Nigeria. Even though their applications enhanced soil fertility (Saxena et al., 1975), several research reports have shown that frequent applications of chemical fertilizers generally lead to soil acidity, immobilization of soil nutrients and decrease in soil organic matter (Agboola and Obigbesan, 1975; Avery, 1995).

The alternative is now found in compost and minimum tillage because of their natural potential to boost soil organic matter and improve soil properties. However, there is need to combine both methods as their sole application has not been reported to guarantee optimum yield when compared to their combined application. For instance, (Ewulo et al., 2011) reported that tillage combined with organic mulch produced significantly higher yield of pepper than the sole application of tillage or mulch, especially when mulch was combined with manual ridging. Similarly, (Nazeer et al., 2012) observed that the combination of farmyard manure and tillage recorded better yield of rice compared with sole application of tillage or farmyard manure. Hence, there is need for appropriate soil management practices that could increase sequestration of carbon and subsequently build up soil organic matter while improving nutrient-use efficiency, water retention capacity and maintaining favourable soil temperature for optimum pepper production in Nigeria. It is possible therefore, that the combination of almond leaf-based compost and tillage could create optimum soil condition for pepper production in Ibadan.

Although, tillage and composts are known to improve soil physical and chemical properties for enhanced crop performance, there is dearth of information on the combined effects of compost and tillage on soil properties and yield of pepper. Therefore, the combined effects of almond leaf-based compost and tillage on soil properties and yield of Capsicum chinense in Ibadan were evaluated.

\section{MATERIALS AND METHODS}

\section{The study area}

The experiment was carried out in Ibadan which is located in the Southwest of Nigeria between latitudes $7^{\circ}$ $25^{\prime}$ and $7^{\circ} 31^{\prime} \mathrm{N}$ and longitudes $3^{\circ} 51^{\prime}$ and $3^{\circ} 56$ ' $\mathrm{E}$ in the Rainforest Zone. Weather data collected in Ibadan, showed annual rainfall of $1625.5 \mathrm{~mm}$, daily air temperature of $27.7^{\circ} \mathrm{C}$ and relative humidity of $79.9 \%$. The soil of the area is Alfisol according to the USDA classification. It is formed from Basement Complex rocks. It is classified locally as Iwo series (Smyth and Montgomery, 1962). The soil of the experimental site has been exhaustively cropped with maize, cassava and vegetables for more than twenty years.

\section{Compost preparation}

Three types of $1: 1 \mathrm{w} / \mathrm{w}$ almond leaf-based compost: Almond leaves + Poultry manure (AP); Almond leaves + Cattle manure (AC); and Almond leaves + Swine manure compost (AS) were composted in 2009 , using a static pile method under a shed located behind the Department of Agronomy, University of Ibadan.

\section{Screen house studies}

The Screen house experiment was conducted in the Screen house of the Department of Agronomy, University of Ibadan, between March and July, 2010. The effects of twelve fertilizer treatments: AP at 9.7, 12.1 and 14.5 t/ha; $\mathrm{AC}$ at $14.3,17.9$ and $21.5 \mathrm{t} / \mathrm{ha}$; $\mathrm{AS}$ at $13.0,16.3$, and 19.6 t/ha; NPK 15-15-15 (0.2, 0.25, and $0.3 \mathrm{t} / \mathrm{ha})$ and a control (without fertilizer) on the growth and yield of Capsicum chinense were investigated in the Screen house. The rate for various compost mixtures was fixed based on $P$ requirement (20 kg P/ha) for pepper (Fagbayide, 1997) in South western, Nigeria. The $P$ varied in the mature compost accounted for the different rates. Each treatment was mixed with $5 \mathrm{~kg}$ soil in pots and the experiment was arranged in a completely randomised design with four replications. The soil used for the study was collected from the experimental site at the Teaching and Research Farm along the Botanical Garden, University of Ibadan. There were two pots per treatment and 26 pots per replicate. One seedling of Capsicum chinense was transplanted into each pot at 4 weeks after sowing (WAS) in the nursery, a week after treatments application, to enhance mineralization. Weeding was carried out on weekly basis.

\section{Field Studies}

The field experiment was carried out between March and 
July, 2011 at the Teaching and Research Farm along the Botanical Garden, University of Ibadan. The field was manually cleared, measured and pegged. Ridges were made with giant African hoe. The size of each plot was $3.0 \times 4.0 \mathrm{~m}\left(12 \mathrm{~m}^{2}\right)$ with plant spacing of $60 \times 60 \mathrm{~cm}$. The plant population was 27,778 plants/ha. The performances of the best rates of each treatment: AP (14.5 t/ha), AC (14.3 t/ha), AS (13.0 t/ha), NPK (0.25 t/ha) and control from the Screen house studies, under two tillage methods: Manual Clearing (MC) and Manual Ridging (MR) were investigated. The ten treatment combinations (MC; AP/MC; AC/MC; AS/MC; NPK/MC; MR; AP/MR; AC/MR; AS/MR and NPK/MR) were laid out in a randomised complete block design with four replications.

Pepper seedlings were transplanted at 4 WAS. Almond leaf-based compost treatments were applied using ring method a week after transplanting, while NPK 15-15-15 was applied using ring method at 2 WAT. Weeding was manually carried out at three weeks interval.

\section{Data collection}

Data were collected on plant height, number of leaves, and number of branches, stem girth and root length of pepper using ten plants per plot at 12 weeks after transplanting in the field. Plant height was taken from the ground level to the tip of the plant, using a measuring tape; stem girth was measured round the stem with a rope at $5 \mathrm{~cm}$ above the ground level while root length of pepper was taken from four plants per plot in each replicate. Each of the pepper plant was uprooted and the main root was measured using a measuring tape. Average fruits weights were determined with the aid of a weighing balance after harvesting.

\section{Plant analysis}

The dried samples of each of the almond leaf-based compost types were milled and sieved with $0.5 \mathrm{~mm}$ wire mesh for the determination of N, P and K. Nitrogen was determined using Micro-Kjeldahl procedure (IITA, 1975). The mixture of concentrated nitric, perchloric and sulphuric acid in the ratio of 25:4:2 respectively, were used to digest $0.5 \mathrm{~g}$ of each sample. Phosphorus was determined using vanadomolybdate yellow colorimetry method (Jackson, 1962), while K was determined by flame photometry.

\section{Soil analysis}

Ten soil samples were randomly collected $(0-15 \mathrm{~cm})$ using an auger before planting in the field. Samples were air-dried, crushed and passed through $2 \mathrm{~mm}$ wire mesh for the determination of $\mathrm{pH}, \mathrm{P}, \mathrm{K}, \mathrm{Ca}, \mathrm{Mg}$ and $\mathrm{Na}$. The soil $\mathrm{pH}$ was determined with a $\mathrm{pH}$ meter using $1: 1$ soil: water ratio. Phosphorus was determined by Bray P1 method and colour was developed in the soil extracts using the ascorbic and acid blue method (Murphy and Riley, 1962). Exchangeable $\mathrm{K}, \mathrm{Ca}, \mathrm{Mg}$ and $\mathrm{Na}$ were determined by neutral ammonium acetate extraction method. Potassium and $\mathrm{Na}$ concentration in the extract were determined using the flame photometer; while $\mathrm{Ca}$ and $\mathrm{Mg}$ were determined by atomic absorption spectrophotometer (Okalebo et al., 1993). Organic carbon and total $\mathrm{N}$ was determined from the soil sieved with $0.5 \mathrm{~mm}$ wire mesh. Soil organic carbon was determined using the Walkley-Black oxidation method (Nelson and Sommers, 1982). Total N was also determined using the Macro-kjeldahl procedure (Bremner and Mulvancy, 1982). Particle size analysis was determined using Bouyoucous hydrometer method (Bouyoucous, 1962). The chemical properties of the soil were determined at 15 weeks after transplanting from five locations per plot per replicate. The physical properties of the soil $(0-15 \mathrm{~cm})$ were determined at 15 WAT from five different locations per plot. Soil bulk density was determined by core method (Blake and Hartage, 1986). Total porosity was calculated from bulk density using a particle density of $2.65 \mathrm{Mg} \mathrm{m}^{-3}$ (Arshad et al., 1996). Soil temperature was determined using a Glass bulb soil thermometer at $3.00 \mathrm{pm}$, Nigerian time.

\section{Statistical analysis}

The data collected were analysed using descriptive statistics and ANOVA. Treatment means that were significantly $(p=0.05)$ different were separated using Duncan multiple range test (DMRT) at $5 \%$ level of probability.

\section{RESULTS AND DISCUSSION}

Table 1 presents the results of the analysis of the soil used for the study. The soil was slightly acidic with a $\mathrm{pH}$ of 6.1, which is within the range (5.5-6.5) for optimum pepper production (Whittaker et al., 1959). Texturally, the soil was sandy loam. The available P $(8 \mathrm{mg} / \mathrm{kg})$, SOC $(7.3 \mathrm{~g} / \mathrm{kg})$ and total $\mathrm{N}(0.9 \mathrm{~g} / \mathrm{kg})$ were below the critical limits of $10-16 \mathrm{mg} / \mathrm{kg}, 8.7 \mathrm{~g} / \mathrm{kg}$ and $1.5 \mathrm{~g} / \mathrm{kg}$ respectively, reported for soils in Southwestern, Nigeria (Adeoye and Agboola, 1985; Sobulo and Adepetu, 1987; Enwezor et al., 1989). The exchangeable cation such as $\mathrm{K}$ and $\mathrm{Ca}$ were below the critical limits of 0.2 and $2 \mathrm{cmol} / \mathrm{kg}$, respectively (Adeoye, 1986; Akinrinde and Obigbesan, $2000)$, while the $M g$ content of the soil $(1.5 \mathrm{cmol} / \mathrm{kg})$ was above the critical limit of $0.4 \mathrm{cmol} / \mathrm{kg}$ (Akinrinde and Obigbesan, 2000). The result of the soil analysis before cropping showed that the soil was not adequate for 
Table 1: Physico-chemical properties of the soil of the experimental site

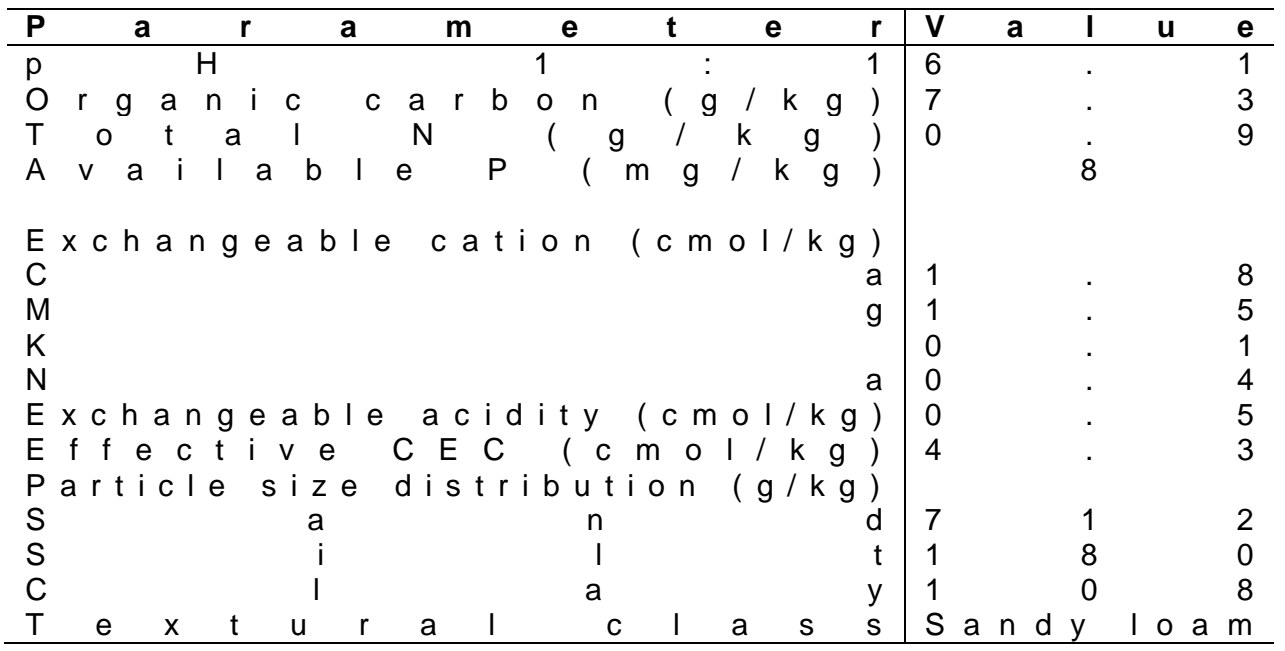

Table 2: Chemical composition of almond leaves-based composts used for the study

\begin{tabular}{|c|c|c|c|c|c|c|c|}
\hline \multicolumn{2}{|c|}{ Compost } & \multirow{2}{*}{$\frac{\mathbf{N}}{\mathrm{g} / \mathrm{kg}}$} & \multicolumn{3}{|c|}{$\mathbf{P}$} & \multicolumn{2}{|c|}{$\mathbf{K}$} \\
\hline & & & $\mathrm{m}$ & g & I & $\mathrm{k}$ & $\mathrm{g}$ \\
\hline A & $P$ & 5.7 & 3 & & 1 & 3 & 9 \\
\hline A & C & 6.0 & 2 & . & 1 & 5 & 7 \\
\hline A & $S$ & 5.2 & 2 & . & 3 & 2 & 6 \\
\hline
\end{tabular}

AP = Almond leaves + Poultry manure compost; $\mathrm{AC}=$ Almond leaves + Cattle manure compost; $A S=$ Almond leaves + Swine manure compost

pepper production. Hence, additional fertilizer input will be required to augment the soil fertility. The plant analysis of almond leaf-based composts as revealed in Table 2 showed that the AP contained $5.7 \mathrm{~g} / \mathrm{kg} \mathrm{N}, 3.1$ $\mathrm{mg} / \mathrm{kg} P$ and $3.9 \mathrm{mg} / \mathrm{kg} \mathrm{K}$; AC had $6.0 \mathrm{~g} / \mathrm{kg} \mathrm{N}, 2.1 \mathrm{mg} / \mathrm{kg}$ $P$ and $5.7 \mathrm{mg} / \mathrm{kg} \mathrm{K}$; and AS had $5.2 \mathrm{~g} / \mathrm{kg} \mathrm{N}, 2.3 \mathrm{mg} / \mathrm{kg} \mathrm{P}$ and $2.6 \mathrm{mg} / \mathrm{kg} \mathrm{K}$. Their composition varied based on the differences in feed and feacal compositions of the various organic material used for the composting (Ewulo et al., 2007).

Under Screen house conditions, almond leaf-based composts and NPK treatments significantly $(p<0.05)$ enhanced plant height, stem girth, number of leaves and branches of pepper compared to the control (Table 3). This was contrary to the report of (Aduloju et al. 2011) who observed that application of raw organic material did not significantly $(p<0.05)$ affected okra plant height and number of leaves with respect to the level of organic material applied during the pot experiment. This showed the ability of the almond leaf-based compost to improve the growth performance of pepper over the raw organic material due to better release of nutrient into the soil for plant use. Thus, the plant height of pepper increased in the order: $19.6 \mathrm{t} / \mathrm{ha}$ AS $(31.3 \mathrm{~cm})<21.5 \mathrm{t} / \mathrm{ha}$ AC $(33.4$ $\mathrm{cm})<0.3 \mathrm{t} / \mathrm{ha}$ NPK $(34.0 \mathrm{~cm})<14.5 \mathrm{t} / \mathrm{ha}$, AP $(34.9 \mathrm{~cm})$; stem girth increased in the order: $0.25 \mathrm{t} / \mathrm{ha}$ NPK $(1.8 \mathrm{~cm})$ $<21.5 \mathrm{t} /$ ha AC $(2.0 \mathrm{~cm})<19.6 \mathrm{t} /$ ha AS $(2.0 \mathrm{~cm})<14.5$ t/ha AP $(2.1 \mathrm{~cm})$; the number of leaves increased in the order: $0.3 \mathrm{t} /$ ha NPK $(36.3)<13.0 \mathrm{t} / \mathrm{ha}$ AS $(43.3)<9.7 \mathrm{t} / \mathrm{ha}$ AP $(44.8)<14.3$ t/ha AC (46.3) and the number of branches increased in the order: 13.0 t/ha AS (6.0) $<0.3$ t/ha NPK $(7.0)<21.5$ t/ha NPK $(7.3)<14.5$ t/ha AP (7.8).

Table 4 shows that the application of almond leafbased compost and NPK treatments significantly $(p<0.05)$ enhanced the number of fruits and fruit yield of pepper when compared to the control. Relative to the control; AP at 9.7, 12.1 and 14.5 t/ha; $A C$ at 9.7, 12.1 and 14.5 t/ha; AS at 13.0, 16.3 and $19.6 \mathrm{t} / \mathrm{ha}$ and NPK at 0.2, 0.25 and $0.3 \mathrm{t} /$ ha significantly $(\mathrm{p}<0.05)$ increased the number of fruits of pepper by $38.5,52.9,75.9,80.8,71.2,36.5,61.5$, 
062 Int. Res. J. Agric. Sci. Soil Sci.

Table 3. Effects of almond leaf-based compost on morphological traits of pepper at 12 WAT in the Screen house

\begin{tabular}{|c|c|c|c|c|c|c|c|c|c|c|c|c|c|c|c|c|c|}
\hline \multirow{2}{*}{\multicolumn{3}{|c|}{$\begin{array}{l}\text { Treatment } \\
\text { Control }\end{array}$}} & \multicolumn{3}{|c|}{ Rate (t/ha) } & \multicolumn{4}{|c|}{ Plant height (cm) } & \multicolumn{3}{|c|}{ Stem girth $(\mathrm{cm})$} & \multicolumn{2}{|c|}{ Number of leaves } & \multicolumn{3}{|c|}{ Number of branches } \\
\hline & & & & 0 & & 2 & 3 & . 8 & $\mathrm{~b}$ & & . 4 & C & 24.8 & C & 3 & . 6 & $c$ \\
\hline \multirow{3}{*}{ A } & & $\mathrm{P}$ & 9 & & 7 & 3 & 3 & & & & $7 \mathrm{ab}$ & C & $8 \mathrm{a}$ & $b$ & 5 & $1 \mathrm{a} \mathrm{b}$ & \\
\hline & & & & 2 & 1 & 3 & 3 & & & & . 9 & a & $39.0 \mathrm{a} \mathrm{b}$ & c & & $5 \mathrm{a}$ & b \\
\hline & & & 1 & 4 & 5 & & 4 & & & & 1 & & $44.0 \mathrm{a}$ & b & & 8 & a \\
\hline \multirow[t]{3}{*}{ A } & & C & 1 & 4 & 3 & & 2 & . & & & . 9 & c & $4 \quad 6.3$ & a & & 0 & a \\
\hline & & & 1 & 7 & 9 & & 2 & & & & $7 \mathrm{ab}$ & c & $31.3 \mathrm{ab}$ & c & 5 & $a b$ & \\
\hline & & & 2 & 1 & 5 & & 3 & & & & . 0 & a & $44.2 a$ & $b$ & & 3 & a \\
\hline \multirow[t]{3}{*}{ A } & & S & 1 & 3 & 0 & 3 & 0 & & & & 9 & a & $3 a$ & $b$ & & $a b$ & c \\
\hline & & & 1 & 6 & 3 & & 0 & & & & & & $8 \mathrm{ab}$ & c & & $3 a b$ & c \\
\hline & & & 1 & 9 & 6 & 3 & 1 & .3 & & & 0 & $a$ & $35.9 \mathrm{ab}$ & c & & $0 \quad b$ & C \\
\hline \multirow[t]{4}{*}{ N } & $\mathrm{P}$ & $\mathrm{K}$ & 0 & . & 2 & 2 & 9 & $6 a$ & b & & $5 \mathrm{~b}$ & 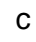 & $29.3 \mathrm{~b}$ & c & 4 & $b$ & C \\
\hline & & & 0 & 2 & 5 & 3 & 1 & . 1 & & & $8 a$ & & $31.0 \mathrm{ab}$ & c & & 7 & b \\
\hline & & & 0 & . & 3 & 3 & 4 & 0 & & & $8 a$ & & $36.3 \mathrm{ab}$ & c & & . $\quad 0$ & a \\
\hline & $E$ & \pm & & & & 1 & & & & & & & & 5 & & & 7 \\
\hline
\end{tabular}

Means with the same letter(s) are not significantly different by Duncan multiple range test at $\mathrm{p}<0.05$, S.E. $\pm=$ Standard error of the differences of means, AP $=$ Almond leaves + Poultry manure compost $; \mathrm{AC}=$ Almond leaves + Cattle manure compost; $\mathrm{AS}=$ Almond leaves + Swine manure compost.

Table 4: Effects of almond leaf-based compost on fruit yield of pepper in the Screen house

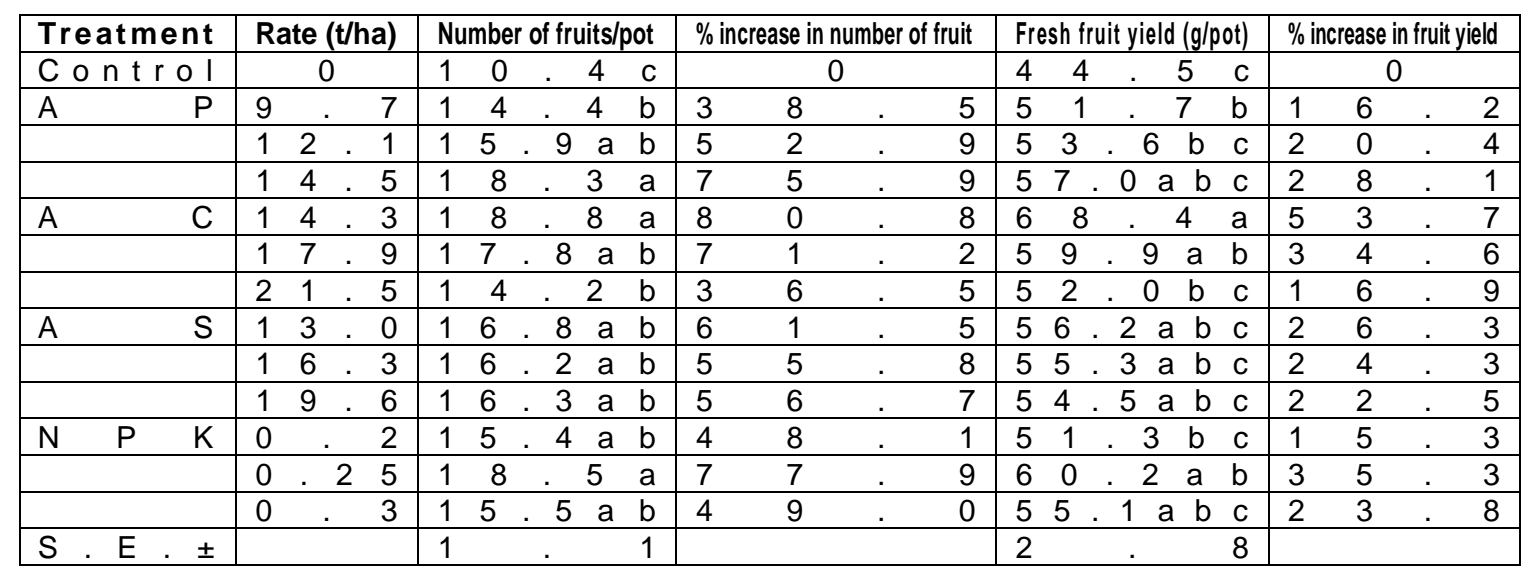

Means with the same letter(s) are not significantly different by Duncan multiple range test at $p<0.05$, S.E. $\pm=$ Standard error of the differences of means, AP = Almond leaves + Poultry manure compost; $A C=$ Almond leaves + Cattle manure compost; AS = Almond leaves + Swine manure compost

55.8, 56.7, 48.1, 77.9 and 49.0\%, respectively. Alike number of fruits, the aforementioned treatments in relation to the control, also increased fruit yield of pepper by $16.2,20.4,28.1,53.7,34.6,16.9,26.3,24.3,22.5$, $15.3,35.3$ and $23.8 \%$ respectively. Furthermore, the AP rates increased fruit yield of pepper in the order: $9.7 \mathrm{t} / \mathrm{ha}$ $(51.7 \mathrm{~g} / \mathrm{pot})<12.1 \mathrm{t} / \mathrm{ha}(53.6 \mathrm{~g} / \mathrm{pot})<14.5 \mathrm{t} / \mathrm{ha}(57.0$ $\mathrm{g} / \mathrm{pot}) ;$ AC rates increased in the order: $21.5 \mathrm{t} / \mathrm{ha}$ (52.0 $\mathrm{g} /$ pot $)<17.9 \mathrm{t} / \mathrm{ha}(59.9 \mathrm{~g} /$ pot $)<14.3 \mathrm{t} / \mathrm{ha}(68.4 \mathrm{~g} /$ pot $) ;$ AS rates increased in the order: $19.6 \mathrm{t} / \mathrm{ha}(54.5 \mathrm{~g} / \mathrm{pot})<16.3$ $\mathrm{t} / \mathrm{ha}(55.3 \mathrm{~g} / \mathrm{pot})<13.0 \mathrm{t} / \mathrm{ha}(56.2 \mathrm{~g} / \mathrm{pot})$ and NPK rates increased in the order: $0.2 \mathrm{t} / \mathrm{ha}(51.3 \mathrm{~g} / \mathrm{pot})<0.3 \mathrm{t} / \mathrm{ha}$
$(55.5 \mathrm{~g} /$ pot $)<0.25 \mathrm{t} / \mathrm{ha}(60.2 \mathrm{~g} /$ pot $)$. The positive effect of the almond leaf-based compost on pepper fruit yield was due to higher mineralization of this organic input which also resulted to better performances than the NPK 15-1515. Similar observation was recorded in the Screen house experiment by (Aduloju et al. 2011). They reported that application of organic fertilizer significantly $(p<0.05)$ increased the fruit yield of okra than the yield obtained from NPK fertilizer.

In the field, almond leaf-based composts: AP (14.5 $\mathrm{t} / \mathrm{ha}), \mathrm{AC}(14.3 \mathrm{t} / \mathrm{ha})$, AS (13.0 t/ha) and NPK (0.25 t/ha) significantly $(p<0.05)$ increased $\mathrm{SOC}, \mathrm{N}, \mathrm{P}, \mathrm{Ca}, \mathrm{Mg}, \mathrm{Na}$ 
Table 5: Effects of almond leaf-based compost on soil chemical properties in the field

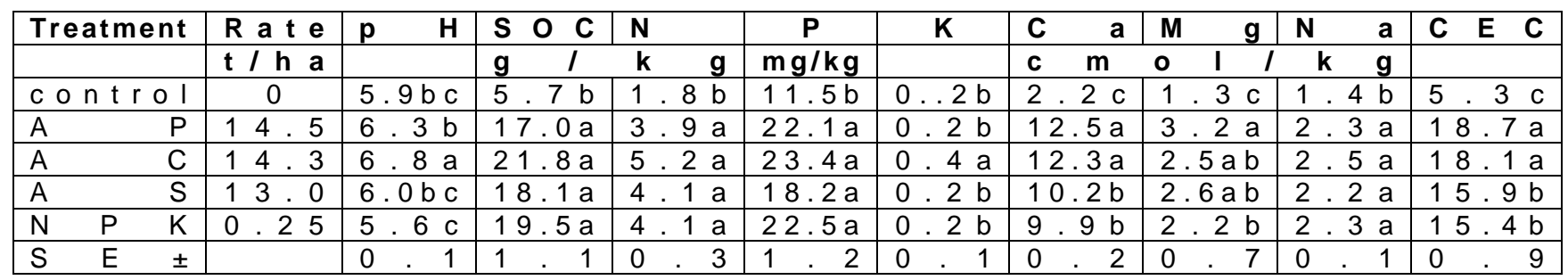

Means with the same letter(s) in a column are not significantly different at $p<0.05$ according to Duncan multiple range test, S.E. \pm $=$ Standard error of the differences of means, AP $=$ Almond leaves + Poultry manure compost, $A C=$ Almond leaves + Cattle manure compost, $A S=$ Almond leaves + Swine manure compost

Table 6: Effects of almond leaf-based compost on yield of pepper in the field

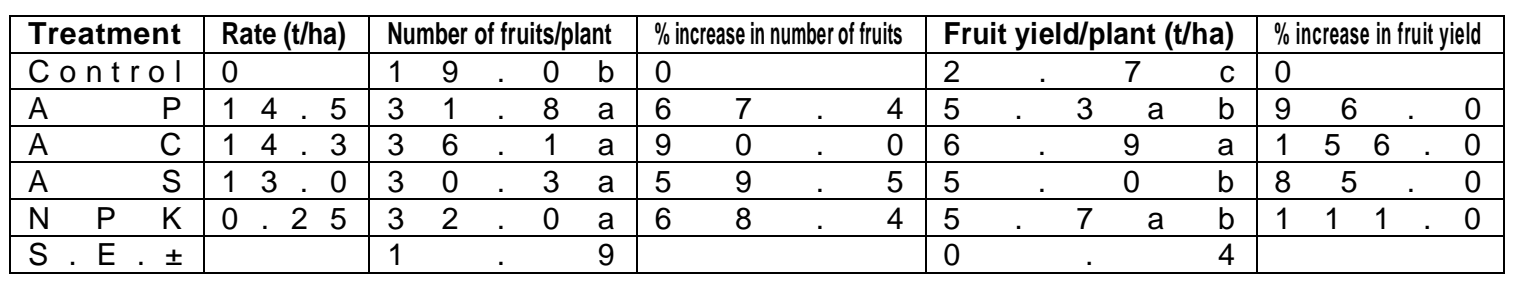

Means with the same letter(s) in a column are not significantly different at $\mathrm{p}<0.05$ according to Duncan multiple range test, S.E. $\pm=$ Standard error of the differences of means, AP = Almond leaves + Poultry manure compost, $A C=$ Almond leaves + Cattle manure compost, $A S=$ Almond leaves + Swine manure compost

Table 7: Effects of tillage on soil physical properties in the field

\begin{tabular}{|c|c|c|c|c|c|c|c|c|}
\hline \multirow{2}{*}{$\begin{array}{l}\text { Tillage method } \\
\text { Manual clearing }\end{array}$} & \multicolumn{2}{|c|}{ Porosity (\%) } & \multicolumn{2}{|c|}{ Bulk density $\left(\mathrm{Mg} / \mathrm{m}^{3}\right)$} & \multicolumn{4}{|c|}{ Temperature $\left({ }^{\circ}\right)$} \\
\hline & 46 & 3. 4 & 1 & 4 & 2 & 8 & . & 8 \\
\hline Manual ridging & 5 & 4 & 1 & 2 & 2 & 8 & . & 6 \\
\hline LSD $(0.05)$ & 4 & 1 & $\mathrm{n}$ & s & $\mathrm{n}$ & & & $\mathrm{s}$ \\
\hline S.E. \pm & 1.4 & & 0.1 & & 0.1 & & & \\
\hline
\end{tabular}

NS $=$ Not significantly different at $p=0.05$, S.E. $\pm=$ Standard error of the differences of means

and CEC (Table 5). This result was similar to that of (Ewulo 2005), who reported that soil pH, SOC, N, P, K, $\mathrm{Ca}, \mathrm{Mg}, \mathrm{Na}$ and $\mathrm{CEC}$ increased with manure application rates. Also, soils treated with $\mathrm{AC}$ compost recorded significantly $(p<0.05)$ higher values of $N, P, K$, and $\mathrm{Na}$ than other treatments. The ability of the $A C$ compost to increase soil N, P, K, and $\mathrm{Na}$ could be attributed to higher storage of carbon in the soil under this treatment than other treatments. The soil $\mathrm{pH}$ was also significantly $(p<0.05)$ increased by almond leaf-based composts than the NPK and control treatment. The lowest $\mathrm{pH}$ was recorded from NPK. This result inferred that the continuous use of chemical fertilizers could result to soil acidity (Avery, 1995). There were significant $(p<0.05)$ increases in the number of fruits and fruit yield of pepper by the almond leaf-based composts and NPK fertilizer, respectively (Table 6). Relative to the control; $A P, A C, A S$ and NPK increased the number of fruits of pepper by $67.4,90.0,59.5$ and $68.4 \%$ respectively, while also increasing the fruit yield of pepper by 96.0, 156.0, 85.0 and $111.0 \%$, respectively. However, the highest fruit yield of pepper was recorded by $14.3 \mathrm{t} / \mathrm{ha} \mathrm{AC}$ compost and it was higher than that of NPK by $21.1 \%$ (Table 6 ). The result was in line with (Aiyelari et al., 2011), who reported that the application of compost at 5 and $10 \mathrm{t} /$ ha gave significant increases in okra pod counts and weight, while also recording 12.6 and $27.5 \%$ higher fresh pod weight than those obtained from NPK fertilizer respectively.

Tables 7, 8, 9 and 10 show the effects of tillage on soil properties, and growth and yield of pepper in the field. 
064 Int. Res. J. Agric. Sci. Soil Sci.

Table 8: Effects of tillage on soil chemical properties in the field

\begin{tabular}{|c|c|c|c|c|c|c|c|c|c|}
\hline Tillage method & $\mathrm{pH}(1: 1)$ & soc & $\mathbf{N}$ & $\mathbf{P}$ & $\mathbf{K}$ & C & M $g$ & $\mathbf{N}$ & CEC \\
\hline & & $g /$ & k g & $\mathrm{mg} / \mathrm{kg}$ & $c$ & 0 & 1 & 1 & $g$ \\
\hline Manual clearing & 6 & 14.4 & 3.3 & 17.9 & 0.2 & 8.3 & 2.3 & 2.1 & 13.4 \\
\hline Manual ridging & 6 & 18.5 & 4.3 & 21.2 & 0.3 & 10.5 & 2.4 & 2.2 & 15.9 \\
\hline $\operatorname{LSD}(0.05)$ & $\mathrm{s}$ & 2.7 & 0.8 & $n \quad s$ & 0.1 & 1.2 & $n \quad s$ & $\mathrm{n}$ & 1.8 \\
\hline S.E. \pm & 0.1 & 1.1 & 0.3 & 1.2 & 0.1 & 0.7 & 0.2 & 0.1 & 0.1 \\
\hline
\end{tabular}

NS $=$ Not significantly different at $p=0.05, S . E . \pm=$ Standard error of the differences of means

Table 9: Effects of tillage on morphological traits of pepper at 12 WAT in the field

\begin{tabular}{|c|c|c|c|c|c|c|c|c|c|c|c|c|c|c|c|}
\hline \multirow{2}{*}{$\frac{\text { Tillage method }}{\text { Manual clearing }}$} & \multicolumn{3}{|c|}{ Plant height (cm)/plant } & \multicolumn{3}{|c|}{ Stem girth $(\mathrm{cm}) /$ plant } & \multicolumn{3}{|c|}{ Number of leaves/plant } & \multicolumn{3}{|c|}{ Number of branches/plant } & \multicolumn{3}{|c|}{ Root length $(\mathrm{cm}) /$ plant } \\
\hline & 2 & 6 & 6 & 1 & & 7 & 4 & 3 & 4 & 9 & & 3 & 1 & 1 & 8 \\
\hline Manual ridging & 3 & 2 & 5 & 2 & & 1 & 6 & 5 & 2 & 1 & 2 & 4 & 1 & 5 & 4 \\
\hline L S D $(0.05)$ & 2 & & 3 & 1 & $\checkmark$ & 6 & 0 & & & 1 & & 9 & 2 & & 7 \\
\hline S.E. \pm & & & & & & & & & & & 0. & & & 0. & \\
\hline
\end{tabular}

S.E. $\pm=$ Standard error of the differences of means

Table 10: Effects of tillage on yield of pepper in the field

\begin{tabular}{|c|c|c|c|c|c|c|c|c|c|c|c|}
\hline Tillage method & \multicolumn{3}{|c|}{ Number of fruits/plant } & \multicolumn{3}{|c|}{$\%$ increase in number of fruits } & \multicolumn{2}{|c|}{ Fruit yield/plant } & \multirow{2}{*}{\multicolumn{3}{|c|}{$\begin{array}{l}\text { \% increase in fruit yild } \\
0\end{array}$}} \\
\hline Manual clearing & 2 & 2 & 4 & & & & 3 & 6 & & & \\
\hline Manual ridging & 3 & 7 & 5 & 6 & 7 & 4 & 6 & 6 & 8 & 3 & 3 \\
\hline $\begin{array}{l}\text { LSD }(0.05) \\
\text { S.E.土 }\end{array}$ & 4 & & 5 & & & & 0 & t & & & \\
\hline
\end{tabular}

S.E. $\pm=$ Standard error of the differences of means

Although, the soil porosity under MR was significantly $(p<0.05)$ higher than MC, the soil bulk density and soil temperature were reduced under $\mathrm{MR}$, and were not significantly $(p<0.05)$ different from those measured under MC (Table 7). Furthermore, the SOC, N, K, Ca, and CEC were significantly $(p<0.05)$ higher under MR than $\mathrm{MC}$, respectively (Table 8 ). However, the soil $\mathrm{pH}, \mathrm{P}$, $\mathrm{Mg}$ and $\mathrm{Na}$ were not significantly $(\mathrm{p}<0.05)$ influenced by the tillage methods, respectively (Table 8 ). On the other hand, the plant height, stem girth, root length, number of leaves and branches of pepper under MR were significantly $(p<0.05)$ higher than MC, respectively (Table 9). Also, the fruit yield of pepper was also significantly $(p<0.05)$ higher under MR than MC (Table 10). The result inferred that MR was better than MC with respect to its effect on soil properties and yield of pepper. This result confirms those of (Awodun et al. 2007), who examined the effects of four tillage methods on the growth and yield of fluted pumpkin. They reported that MR recorded the highest values for number of leaves, number of branches, length of vines and vegetable yields when compared to bed and heap methods respectively, while the least performance was recorded by the flat method.

Tables 11, 12 and 13 show the effects of the various combinations of almond leaf-based compost and tillage on soil properties and yield of pepper in the field. The results showed that there were significant interactions between almond leaf-based compost and tillage on soil properties and yield of pepper in the field. The combination of almond leaf-based composts with MR increased soil porosity, SOC, N, P, Ca, Mg and CEC over its combination with $M C$ (Tables 11 and 12). This confirms that the combination of compost and MR was superior to compost combination with MC. The reduction in soil bulk density which led to an increase in soil porosity under MR could be attributed to its loosening effects on the soil structure. This could be of benefit for crop growth due to its enhancement of easy penetration of plant root for nutrient uptake. Moreover, soil bulk density and soil temperature under the combination of compost and MR were low when compared to sole MC, sole MR and compost combined with MC, respectively. In 
Table 11: Effects of almond leaf-based compost and tillage combinations on soil physical properties in the field

\begin{tabular}{|c|c|c|c|c|c|c|c|}
\hline Treatment & \multirow{2}{*}{$\frac{\text { Rate (t/ha) }}{0}$} & \multicolumn{2}{|c|}{ Bulk density $\left(\mathrm{Mg} / \mathrm{m}^{3}\right)$} & Porosity (\%) & \multicolumn{3}{|c|}{ Temperature $\left({ }^{\circ} \mathrm{C}\right)$} \\
\hline $\mathrm{M} \quad \mathrm{C}$ & & 1.7 & $\mathrm{a}$ & $35.9 \mathrm{~d}$ & 29 & .4 & $\mathrm{~b}$ \\
\hline M $\quad \mathrm{R}$ & 0 & 5 & $b$ & $45.3 \mathrm{c}$ & 3 & 4 & $\mathrm{a}$ \\
\hline NPK/MC & 0.25 & $4 \mathrm{~b}$ & c & $49.1 \mathrm{abc}$ & 28 & $5 \mathrm{~b}$ & $\mathrm{c}$ \\
\hline NPK/MR & 0.25 & . 1 & d & $56.6 \mathrm{ab}$ & 28 & $5 \mathrm{~b}$ & $\mathrm{c}$ \\
\hline $\mathrm{AS} / \mathrm{MC}$ & 13.0 & . $4 \mathrm{~b}$ & c & $48.1 \mathrm{bc}$ & 29 & $0 \mathrm{~b}$ & $\mathrm{c}$ \\
\hline A S / M R & 13.0 & $2 \mathrm{~b} \mathrm{c}$ & $d$ & $54.7 \mathrm{ab}$ & 29 & . 3 & b \\
\hline$A P / M C$ & 14.5 & . $4 \mathrm{~b}$ & c & $49.1 \mathrm{abc}$ & 2 & 2 & c \\
\hline A P / M R & 14.5 & . $2 \mathrm{~b} \mathrm{c}$ & $d$ & $55.7 \mathrm{ab}$ & 2 & 0 & \\
\hline $\mathrm{AC} / \mathrm{MC}$ & 14.3 & $3 \mathrm{~b} \mathrm{c}$ & $d$ & $50.0 \mathrm{abc}$ & 2 & 0 & c \\
\hline A C / M R & 14.3 & . 1 & $d$ & $59.5 \mathrm{a}$ & 28 & 0 & c \\
\hline S.E. \pm & & 0 & 1 & 1 & 0 & & 1 \\
\hline
\end{tabular}

Means with the same letter(s) in a column are not significantly different at $\mathrm{p}<0.05$ according to Duncan multiple range test, S.E. $\pm=$ Standard error of the differences of means, $M C=$ Manual clearing, $\mathrm{MR}=$ Manual ridging, $\mathrm{AP}=$ Almond leaves + Poultry manure compost, $\mathrm{AC}=$ Almond leaves + Cattle manure compost, $\mathrm{AS}=$ Almond leaves + Swine manure compost

Table 12: Effects of almond leaf-based compost and tillage combinations on soil chemical properties in the field

\begin{tabular}{|c|c|c|c|c|c|c|c|c|c|c|c|}
\hline Treatment & Rate & $\mathbf{H}$ & SOC & $\mathbf{N}$ & $\mathbf{P}$ & $\mathrm{K}$ & C & $\mathbf{M}$ & $\mathbf{N}$ & $C$ & C \\
\hline & $\mathrm{t} / \mathrm{ha}$ & & g / & k $\quad \mathrm{g}$ & $\mathrm{mg} / \mathrm{kg}$ & & $\mathrm{c} \mathrm{mo}$ & / $/ \mathrm{kg}$ & & & \\
\hline M & 0 & $6.0 \mathrm{~cd}$ & $3.3 d$ & $0.6 \mathrm{c}$ & $8.4 \mathrm{~b}$ & $0.1 \mathrm{~b}$ & $1.9 d$ & $1.2 \mathrm{c}$ & $1.4 \mathrm{~b}$ & 4.8 & c \\
\hline M & 0 & $5.9 \mathrm{~cd}$ & $8.1 \mathrm{c}$ & $3.0 \mathrm{~b}$ & 14.6ab & $0.2 b$ & $2.6 \mathrm{~d}$ & $1.4 \mathrm{bc}$ & $1.4 \mathrm{~b}$ & 5.9 & c \\
\hline NPK/MC & 0.25 & $5.4 \mathrm{~d}$ & $17.5 b$ & $4.0 \mathrm{~b}$ & $20.8 a$ & $0.3 b$ & $8.2 \mathrm{c}$ & 2.3abc & $2.2 \mathrm{a}$ & 13.7 & $b$ \\
\hline NPK/MR & 0.25 & $5.8 \mathrm{~cd}$ & $21.5 a$ & $4.1 \mathrm{~b}$ & $24.3 a$ & $0.2 b$ & 11.6ab & $2.1 a b c$ & $2.3 \mathrm{a}$ & $17.1 \mathrm{a}$ & $b$ \\
\hline AS/MC & 13.0 & $6.1 \mathrm{bcd}$ & $17.0 \mathrm{~b}$ & $4.2 \mathrm{~b}$ & $17.8 \mathrm{ab}$ & $0.2 b$ & $8.8 b c$ & 2.3abc & $2.2 \mathrm{a}$ & $14.1 \mathrm{~b}$ & $b$ \\
\hline AS/MR & 13.0 & $5.9 \mathrm{~cd}$ & $19.1 b$ & $4.0 \mathrm{~b}$ & $18.7 \mathrm{a}$ & $0.3 b$ & $11.6 a b$ & $3.0 \mathrm{ab}$ & $2.3 \mathrm{a}$ & $17.7 \mathrm{a}$ & $b$ \\
\hline $\mathrm{AP} / \mathrm{MC}$ & 14.5 & $6.5 a b c$ & $16.0 \mathrm{~b}$ & $3.1 \mathrm{~b}$ & $20.5 a$ & $0.2 b$ & $11.5 \mathrm{ab}$ & $3.0 \mathrm{ab}$ & $2.0 \mathrm{a}$ & $17.5 \mathrm{a}$ & $b$ \\
\hline$A P / M R$ & 14.5 & $6.1 \mathrm{bcd}$ & $18.2 b$ & $4.0 \mathrm{~b}$ & $23.7 a$ & $0.3 b$ & $13.5 a$ & $3.3 \mathrm{a}$ & $2.2 \mathrm{a}$ & 19.9 & a \\
\hline $\mathrm{AC} / \mathrm{MC}$ & 14.3 & $6.8 \mathrm{a}$ & $18.1 \mathrm{~b}$ & $4.1 \mathrm{~b}$ & $22.1 \mathrm{a}$ & $0.3 b$ & $11.3 a b$ & 2.6abc & $2.1 \mathrm{a}$ & $16.7 \mathrm{a}$ & $b$ \\
\hline$A C / M R$ & 14.3 & $6.8 \mathrm{a}$ & $25.5 a$ & $6.4 \mathrm{a}$ & $24.7 a$ & $0.5 \mathrm{a}$ & $13.3 a$ & 2.4abc & $2.0 \mathrm{a}$ & 19.2 & a \\
\hline S.E. \pm & & 0.1 & 1.1 & 0.3 & 1.2 & 0.1 & 0.2 & 0.7 & 0.1 & 0.9 & 9 \\
\hline
\end{tabular}

Means with the same letter(s) in a column are not significantly different at $p<0.05$ according to Duncan multiple range test, S.E. \pm = Standard error of the differences of means, MC = Manual clearing, $\mathrm{MR}=$ Manual ridging, $\mathrm{AP}=$ Almond leaves + Poultry manure compost, $\mathrm{AC}=$ Almond leaves + Cattle manure compost, AS = Almond leaves + Swine manure compost.

a similar study, (Ojeniyi, 1981) found that for sandy soils of Southwestern Nigeria, soils under MC had a higher bulk density and lower porosity than those that were mechanically tilled. The highest value of soil $\mathrm{pH}$ (6.8) was recorded by $\mathrm{AC} / \mathrm{MR}$ and $\mathrm{AC} / \mathrm{MC}$ respectively, while the least value of 5.4 was recorded by NPK-tillage combinations.

This perhaps, explains the reason for the call for a reduced dependence on chemical fertilizer use (Rodale, 1995). The combination of $A C$ and $M R$ recorded significantly $(\mathrm{p}<0.05)$ higher values for $\mathrm{pH}, \mathrm{SOC}, \mathrm{N}, \mathrm{P}, \mathrm{K}$ and $\mathrm{Ca}$. than other treatments, respectively. It could be inferred that the combination of $A C$ and $M R$ had higher capacity to build up soil organic matter which is critical to soil functioning. The fruit yield of pepper was significantly $(p<0.05)$ higher under the combination of compost and 
066 Int. Res. J. Agric. Sci. Soil Sci.

Table 13: Effects of almond leaf-based compost and tillage combinations on fruit yield of pepper

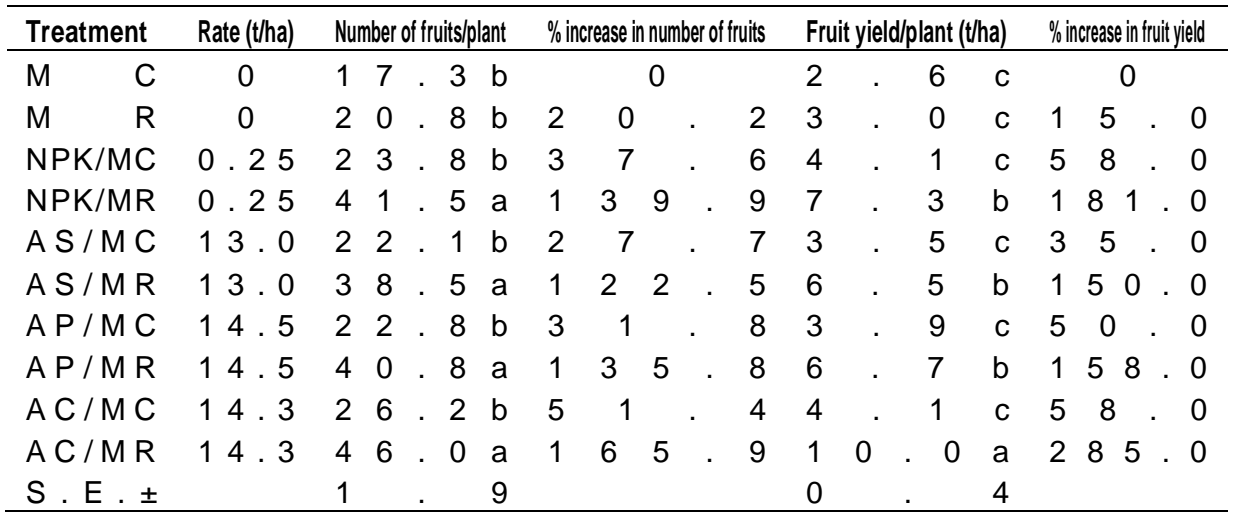

Means with the same letter(s) in a column are not significantly different at $p<0.05$ according to Duncan multiple range test, S.E. \pm = Standard error of the differences of means, $\mathrm{MC}=$ Manual clearing, $\mathrm{MR}=$ Manual ridging, $\mathrm{AP}=$ Almond leaves + Poultry manure compost, $\mathrm{AC}=$ Almond leaves + Cattle manure compost, $\mathrm{AS}=$ Almond leaves + Swine manure compost

MR than compost-MC combinations (Table 3.13). However, relative to the MC; MR, NPK/MC, NPK/MR, AS/MC, AS/MR, AP/MC, AP/MR, AC/MC and AC/MR significantly $(p<0.05)$ increased the fruit yield of pepper by $15,58,181,35,150,50,158,58$ and $285 \%$ respectively. The optimum fruit yield of pepper (10.0 t/ha) recorded by the combination of 14.3 t/ha $\mathrm{AC} / \mathrm{MR}$ was higher than the NPK/MR combination by $27.0 \%$. The $\mathrm{AC} / \mathrm{MR}$ combination also had better fruit yield than $\mathrm{MC}$, MR and almond leaf-based compost treatments, respectively. A similar result was reported by (Nazeer et al., 2012) who observed that the combination of farmyard manure and tillage recorded better rice yield than sole tillage or farmyard manure application, respectively.

In this study, compost was suitably combined with manual ridging for optimum production of pepper. This soil management practice employs the most useful way of removing almond leaf and manure wastes from the environment. However, results of previous investigations (Awodun et al., 2007; Ayeni et al., 2008) only emphasized on the use of freshly collected organic wastes to improve soil fertility and yield of crops with little or no consideration for appropriate tillage methods to complement the potentials of this manure. However, almond leaf-based compost plus tillage treatments: (AP/MR, AS/MR, NPK/MR and AC/MR) increased soil organic carbon relative to MR by $125.0,136.0,165.0$ and $215.0 \%$. This shows that the combination of almond-leaf based compost and tillage methods had higher potential for carbon sequestration than NPK combinations. The $\mathrm{pH}$ of the soil was also increased by compost and tillage combinations. This was contrary to the result of $\mathrm{pH}$ observed from NPK plus tillage, which decreased the $\mathrm{pH}$ of the soil compared to the pre-planting value (6.1). However, the optimum fruit yield of pepper (10 t/ha) by AC (14.3 t/ha) under manual ridging was significantly $(p<0.05)$ higher than other treatments due to the ability of the treatment to produce the highest number of branches of pepper. Therefore, it could be inferred that the more the branches the higher the yield. Hence, research efforts should be concentrated on developing pepper plant that would be able to produce more branches for fruit production.

Although, all the compost treatment combinations with tillage were found to significantly improve soil properties and yield of pepper throughout the study, the most effective compost that combined optimally with manual ridging (MR) was $\mathrm{AC}$ compost at $14.3 \mathrm{t} / \mathrm{ha}$.

\section{CONCLUSION}

The combination of almond leaf-based compost and manual ridging significantly enhanced soil fertility. However, application of almond leaf-cattle manure compost at $14.3 \mathrm{t} / \mathrm{ha}$ was the most effective among the treatment combinations investigated, and thus, recommended for pepper production in Ibadan.

\section{REFERENCES}

Adeoye GO (1986). Comparative studies of ammonium bifluoride chelate extractant and some conventional extractants for sedimentary soils of southwestern Nigeria. Ph.D. Thesis. Department of Agronomy. Uni. Ibadan.xiv + 245pp.

Adeoye GO, Agboola AA (1985). Critical level for soil pH, available P. K. 
$\mathrm{Zn}$. and maize ear leaf content of P. Cu. and Mn in sedimentary soils of Southwestern, Nigeria. Fertilizer Res. 6: 65-71.

Aduloju MO, Fawole OB, Abubakar AJ, Olaniyan JO (2011). Effects of sawmill wastes, animal manure and NPK fertilizer on the performance of okra (Abelmoschusesculentus I. Moench) on an Alfisol. Proceedings of Intl. Soil Tillage Res. Organization.21-24 February, 2011. Ogunlela, A.O. Eds. Uni. of Ilorin, Nigeria.379-384.

Agboola AA, Obigbesan GO (1975). Inter-relations between organic and mineral fertilizers in the tropical rainforest of western Nigeria. In: Organic material fertilizers. FAO Soil Bulletin 27:337-351.

Aiyelari EA Ogunsesin A, Adeoluwa OO (2011) Effects of Terminaliacatappa leaves with poultry manure compost, mulching and seedbed preparation on the growth and yield of okra (AbelmoschusesculentusL Moench). Proceedings of Intl. Soil Tillage Res. Organization.21-24 ${ }^{\text {th }}$ Feb., 2011.Ogunlela, A.O. Eds. Uni. Ilorin, Nigeria.356-370.

Akinrinde, EA, Obigbesan GO (2000). Evaluation of the fertility status of selected soils for crop production on five ecological zones of Nigeria. Proceedings of the $26^{\text {th }}$ Annual Conference of Soils Science Society of Nigeria.30 October - 3 November, 2000. Ibadan. 279288.

Arshad MA, Lowery B, Grossman B (1996). Physical tests for monitoring soil quality. In: Doran, J.W. and Jones, A.J. Eds. Soil Sci. Society American J. 49: 123-142.

Asawalam EF Emeasor KC, Okezie JC (2007). Control of pests of some Capsicum species cultivars using soil amendments in Umudike, Nigeria. Electronic J. Environmental, Agric. and Food Chem. 6: 1975-1979.

Avery, D.T. 1995. Saving the planet with pesticides and plastic. The environmental triumph of high yielding farming. Hudson Institute, Indianapolis. 44.

Awodun MA Omonijo LI, Ojeniyi SO (2007). Effects of Goat Dung and N.P.K. fertilizer on soil and leaf nutrient content, growth and yield of pepper. Intl. J. Soil Sci. 2: 142-147.

Ayeni LS, Adetunji MT, Ojeniyi SO, Ewulo BS, Adeyemo AJ (2008). Comparative and cumulative effect of cocoa pod husk ash and poultry manure on soil and maize nutrient contents and yield. American-Eurosian J. Sustainable Agric. 2: 92-97.

Blake GR, Hartage KH (1986). Bulk density. In: Klute A. (ed.). Methods of soil analysis Part 1 (Agronomy) Inc. Madison, U.S.A. American Society of Agronomy 503-507.

Bouyoucos GJ (1962). Hydrometer method improved for making size analysis of soils. Agronomy J. 54: 464-465.

Bremner JM, Mulvancy CS (1982). Total Nitrogen In: Page, A.L., Miller, R.H. and Keeney, D.R. (Eds.). Method of soil analysis. American society of Agronomy and Soil Sci. Society of America. Madison, Wisconsin, USA. 595-624.

Enwezor WO, Udo EJ, Usoroh NJ, Ayotade KA, Adepetu JA, Chude UO, Udegbe $\mathrm{Cl}$ (1989). Fertilizer use and management practices for crops in Nigeria.2: 163.

Ewulo BS (2005). Effects of poultry dung and cattle manure on chemical properties of clay and sandy clay loam soil. J. Animal and Veterinary Advances 4: 839-841.

Ewulo BS, Hassan KO, Ojeniyi SO (2007).Comparative effect of cow dung manure on soil and leaf nutrient and yield of pepper. Intl. J. Agric. Res. 2: 1043-1048.
Ewulo BS, Ojeniyi SO, Morenikeji Cl (2011). Tillage and mulch influence on soil physical properties, plant nutrient composition and performance of pepper (Capsicum annuumL.) and sorghum (Sorghum Bicolor L.). Intl. Res. J. Agric. Sci. 11: 485-490.

Fagbayide JA (1997). Growth and nutrient concentration of pepper fruits as affected by fertilizer phosphorus. Proceedings of Nigerian Society of Horticultural Sci. 15: 40-42.

Food and Agricultural Organization (2001). FAO statistics estimate world production of Capsicum pepper. Retrieved March 11, 2009 , from http://www.prota-4u.org/protav8asp

Hanson RG (1992). Optimum phosphate fertilizer products and practices for tropical climate agriculture. In: International workshop on phosphate fertilizers and the environment. Intl. Fertilizer Development Center. Muscle Shoals, Alabama, USA. 66-75.

International Institute of Tropical Agriculture (I.I.T.A). 1975. Selected methods for soil and plant analysis. I.I.T.A. Ibadan, Nigeria.

Jackson ML (1962). Soil chemical analysis. Advance Course PrenticeHall, New-york.

Murphy J, Riley JP (1962). A modified single solution method for the determination of phosphate in neutral water. Analytical Chemical acta. 27: 31-36.

Nazeer SAU, Malik G, Nazir, Ahmad J (2012). Effectiveness of tillage systems and farm manure levels on rice productivity. J. Animal and Plant Sci. 22: 334-338.

Nelson DW, Sommers IE (1982). Total organic carbon and organic matter. In: methods of soil analysis Part 2. Agronomy Monograph 9 American Society of Agronomy. Madison WI. 539-594

Ojeniyi SO (1981). In: Adeyemo, A.J. and Agele, S.O (2010). Effects of tillage and manure application on soil physicochemical properties and yield of maize grown on a degraded intensively tilled Alfisol in Southwestern Nigeria. J. Soil Sci. and Environmental Managt. 18: 205-216.

Okalebo JR Gathual KW, Woomer PL (1993). Laboratory methods of soil and plant analysis: a working manual. Tropical Soil Biology and Fertility Programme (TSBF), Nairobi, Kenya. 88.

Rodale R (1995). Your farm worth more than ever put your farms internal resources to work. New farm: Magazine regenerative agricultural. 8.

Saxena GK Locasio SJ Lucas JB (1975). Effect of N, P, K on response of cabbage and tomato grown on a coastal clony soil of Guyana.Tropical Agriculture 52:149-146

Smyth SJ, Montgomery RF (1962). Soils and land use in central western Nigeria. The Government of Western Nigeria Press, Ibadan. 265.

Sobulo RA, Adepetu JA (1987). Soil testing and fertilizer formulation for crop production in Nigeria. Proceedings of the National Fertilizer Seminar. 28-30 ${ }^{\text {th }}$ October, 1987. Port Harcourt, Nigeria. 93-105.

Whittaker CW, Anderson MS, Reitemeier (1959). Liming soils, an aid to better farming. USDA farmers Bulletin 2124. 